\title{
Effects of ultrasound, shortwaves, and physical exertion on pregnancy outcome in physiotherapists
}

\author{
Helena Taskinen, Pentti Kyyrönen, Kari Hemminki
}

\begin{abstract}
Study objective-The aim of the study was to investigate whether occupational exposure among physiotherapists is associated with spontaneous abortion or congenital malformation in the offspring.

Design-The study was a retrospective nested case-control study, where the pregnancy outcome data were based on the medical registers.

Setting-All registered physiotherapists in Finland who had become pregnant during the study period were included in the study.

Subjects-Cases were defined as women who had been treated for spontaneous abortion during 1973-1983 or had delivered a malformed child during 1973-1982. One pregnancy per woman was randomly selected for the study. Three age matched ( \pm 18 months) controls were selected for each abortion case and five for each malformation case. The final study population was 204 cases and 483 controls in the spontaneous abortion study, and 46 cases and 187 controls in the congenital malformation study.
\end{abstract}

Measurements and main resultsExposure information was collected by mailed questionnaires from 1329 women. The response rate was $92 \%$ in the spontaneous abortion study, and $89 \%$ in the congenital malformation study. Heavy lifting (including patient transfers) was associated significantly with spontaneous abortion. Exposure to ultrasound and shortwaves showed about threefold odds ratios for spontaneous abortions occurring after the 10th week of gestation but in analysis where potential confounding variables were controlled, neither reached statistical significance. Deep heat therapies together, and shortwaves alone, were associated significantly with congenital malformations, but the increase was found in the lower exposure category only. From the potential confounding variables, previous abortion (spontaneous or induced) was associated significantly with spontaneous abortion, and febrile disease in early pregnancy was associated with congenital malformation.

Conclusion-Physical exertion during early pregnancy seems to be a risk factor for spontaneous abortion. The findings raise suspicion of the potential harmful effect of shortwaves and ultrasound on the pregnancy, but no firm conclusion can be drawn on the bases of these results alone.
Shortwaves, microwaves, ultrasound, and various superficial electric currents are used in physiotherapy. Knowledge of the effects of shortwaves and microwaves on health is limited and inconclusive. ${ }^{1}$ The primary biological effect is thought to be via hyperthermia. ${ }^{2}$ Increased risk of adverse pregnancy outcome was suggested among physiotherapists using shortwaves in one study, ${ }^{3}$ whereas plastic welders, who use shortwave equipment, displayed no reproductive effects. ${ }^{4}$ The results, however, were based on small numbers in both studies, and thus they do not allow definite conclusions. The work tasks of physiotherapists may also include physical strain in connection with massage, mobilisation therapy, and patient transfers. Physical strain, particularly heavy lifting, has in some studies been found to be a risk factor of spontaneous abortions, but not in others. $^{5}$

This nested case-control study was conducted to investigate whether the occupational exposure of physiotherapists is correlated with spontaneous abortion or congenital malformation in the offspring. All registered physiotherapists in Finland were the source population in this nationwide study.

\section{Methods}

The study subjects, female physiotherapists, were identified from the Central Register of Health Care Personnel, which has information on about 5000 physiotherapists. Knowledge of pregnancies among physiotherapists was obtained by linking the personnel file with the hospital discharge register, which was supplemented with clinic data on spontaneous abortions. The personnel file was also linked with the Finnish Register of Congenital Malformations. Both registers are maintained by the National Board of Health. Descriptions of the coverage and reliability of the registers have been published. 67

The study was conducted with a case-control design. Those physiotherapists (aged 20-39 years) who had been treated in hospital or clinic for spontaneous abortion (ICD-8, codes 643 and 645) between the years 1973 and 1983 were defined as cases of spontaneous abortion. The cases for the congenital malformation study were selected from among those physiotherapists who had given birth to a malformed child between the years 1973 and 1982. Subluxations of the hip (ICD-8 code $755 \cdot 6$ ) were excluded.

The controls for both study groups were selected from among physiotherapists who had given birth to a normal child. Three controls per case were selected in the spontaneous abortion study and five controls per case in the malformation study, using individual matching of
Institute of 00250 Helsinki,

H Taskinen

P Kyyrönen
K Hemminki

Correspondence to: Dr Taskinen

Accepted for publication November 1989 
age ( \pm 18 months). If a woman had had several abortions or births, only one pregnancy was chosen randomly as a study pregnancy.

Questionnaires were mailed in 1986 (three mailings) to the cases and controls requesting information on employment, occupation, use of therapeutic equipment, patient transfers or heavy lifting, personal habits, chronic diseases and febrile diseases during the first three months of the study pregnancy. Pregnancy history was also requested.

For the exposure assessment, the equipment used in the treatment was classified according to the mode of action. Shortwaves, ie, continuous or intermittent electromagnetic fields usually at a frequency of $27 \cdot 12 \mathrm{MHz}$ (wave length $12 \cdot 2 \mathrm{~cm}$ ) were defined as "deep heat therapy" since they

Table I The odds ratio (OR) of spontaneous abortions for individual occupational variables, logistic regression models

\begin{tabular}{|c|c|c|c|}
\hline Variable & $\begin{array}{l}n \\
\text { (case/control) }\end{array}$ & $O R$ & $\begin{array}{l}95^{\circ} \text { o confidence } \\
\text { interval }\end{array}$ \\
\hline $\begin{array}{l}\text { Student during pregnancy } \\
\text { Employed during pregnancy } \\
\text { Not employed during pregnancy }\end{array}$ & $\begin{array}{c}6 / 13 \\
173 / 409 \\
25 / 61\end{array}$ & $\begin{array}{l}1 \cdot 1 \\
1 \cdot 1 \\
\text { reference }\end{array}$ & $\begin{array}{l}0 \cdot 4-3 \cdot 1 \\
0 \cdot 6-1 \cdot 8\end{array}$ \\
\hline $\begin{array}{c}\text { Deep heat therapy } \\
1-4 \mathrm{~h} / \text { week } \\
\geqslant 5 \mathrm{~h} / \text { week }\end{array}$ & $\begin{array}{l}35 / 75 \\
32 / 57\end{array}$ & $\begin{array}{l}1.2 \\
1.6\end{array}$ & $\begin{array}{l}0 \cdot 8-1 \cdot 9 \\
1 \cdot 0-2 \cdot 7\end{array}$ \\
\hline $\begin{array}{c}\text { Shortwaves } \\
1-4 \mathrm{~h} / \text { week } \\
\geqslant 5 \mathrm{~h} / \text { week } \\
\text { Microwaves }\end{array}$ & $\begin{array}{l}34 / 73 \\
30 / 55 \\
13 / 18\end{array}$ & $\begin{array}{l}1 \cdot 2 \\
1.6 \\
1 \cdot 8\end{array}$ & $\begin{array}{l}0 \cdot 7-1 \cdot 9 \\
0 \cdot 9-2 \cdot 7 \\
0 \cdot 8-4 \cdot 1\end{array}$ \\
\hline $\begin{array}{l}\text { Ultrasound } \\
\qquad \begin{array}{l}1-9 \mathrm{~h} / \text { week } \\
\geqslant 10 \mathrm{~h} / \text { week } \\
\geqslant 20 \mathrm{~h} / \text { week }\end{array}\end{array}$ & $\begin{array}{l}94 / 223 \\
12 / 25 \\
9 / 8\end{array}$ & $\begin{array}{l}1 \cdot 1 \\
1 \cdot 2 \\
3 \cdot 4\end{array}$ & $\begin{array}{l}0 \cdot 8-1 \cdot 6 \\
0 \cdot 6-2 \cdot 6 \\
1 \cdot 2-9 \cdot 0^{\star}\end{array}$ \\
\hline $\begin{array}{l}\text { Electric therapies } \\
1-4 \mathrm{~h} / \text { week } \\
\geqslant 5 \mathrm{~h} / \text { week } \\
\text { Diadynamic currents }\end{array}$ & $\begin{array}{l}51 / 129 \\
17 / 23\end{array}$ & $\begin{array}{l}1 \cdot 0 \\
2 \cdot 0\end{array}$ & $\begin{array}{l}0 \cdot 7-1 \cdot 5 \\
1 \cdot 0-3 \cdot 9^{\star}\end{array}$ \\
\hline $\begin{array}{l}1-4 \mathrm{~h} / \text { week } \\
\geqslant 5 \mathrm{~h} / \text { week } \\
\text { Transcutaneous nerve stimulation }\end{array}$ & $\begin{array}{l}31 / 73 \\
10 / 15\end{array}$ & $\begin{array}{l}1.0 \\
1.9\end{array}$ & $\begin{array}{l}0.6-1 \cdot 6 \\
0.8-4 \cdot 4\end{array}$ \\
\hline $\begin{array}{l}1-4 \mathrm{~h} / \text { week } \\
>5 \mathrm{~h} / \text { week } \\
\text { Interference } \\
\text { Electrogalvanic stimulation } \\
\text { Electric activation }\end{array}$ & $\begin{array}{l}31 / 75 \\
9 / 15 \\
5 / 15 \\
3 / 2\end{array}$ & $\begin{array}{l}1 \cdot 1 \\
1 \cdot 6 \\
0 \cdot 9 \\
4 \cdot 2\end{array}$ & $\begin{array}{l}0 \cdot 6-1 \cdot 6 \\
0 \cdot 7-3 \cdot 8 \\
0 \cdot 3-2 \cdot 4 \\
0 \cdot 7-25 \cdot 0\end{array}$ \\
\hline $\begin{array}{l}1-4 \mathrm{~h} / \text { week } \\
\geqslant 5 \mathrm{~h} / \text { week }\end{array}$ & $\begin{array}{c}15 / 37 \\
3 / 4\end{array}$ & $\begin{array}{l}1 \cdot 0 \\
2 \cdot 0\end{array}$ & $\begin{array}{l}0.5-1.9 \\
0.4-9.0\end{array}$ \\
\hline $\begin{array}{l}\text { Superficial heat therapy } \\
1-4 \mathrm{~h} / \text { week } \\
\geqslant 5 \mathrm{~h} / \text { week } \\
\text { Infrared }\end{array}$ & $\begin{array}{l}42 / 103 \\
12 / 25\end{array}$ & $\begin{array}{l}1 \cdot 0 \\
1 \cdot 4\end{array}$ & $\begin{array}{l}0.7-1 \cdot 5 \\
0.8-2 \cdot 7\end{array}$ \\
\hline $\begin{array}{l}1-4 \mathrm{~h} / \text { week } \\
\geqslant 5 \mathrm{~h} / \text { week } \\
\text { Ultraviolet light } \\
\text { Hydrocollator heating packages }\end{array}$ & $\begin{array}{l}41 / 90 \\
12 / 25 \\
3 / 4\end{array}$ & $\begin{array}{l}1 \cdot 2 \\
1.3 \\
1 \cdot 8\end{array}$ & $\begin{array}{l}0 \cdot 8-1 \cdot 8 \\
0 \cdot 4-8 \cdot 3 \\
0 \cdot 4-8 \cdot 3\end{array}$ \\
\hline $\begin{array}{l}1-4 \mathrm{~h} / \text { week } \\
\geqslant 5 \mathrm{~h} / \text { week }\end{array}$ & $\begin{array}{l}16 / 39 \\
10 / 16\end{array}$ & $\begin{array}{l}1 \cdot 1 \\
1 \cdot 8\end{array}$ & $\begin{array}{l}0 \cdot 6-2 \cdot 0 \\
0 \cdot 8-4 \cdot 0\end{array}$ \\
\hline Heavy lifting $\mathbf{1}_{2}^{\mathrm{a}}$ & $\begin{array}{l}91 / 210 \\
11 / 10\end{array}$ & $\begin{array}{l}1 \cdot 2 \\
3 \cdot 5\end{array}$ & $\begin{array}{l}0 \cdot 8-1 \cdot 7 \\
1 \cdot 1-9 \cdot 0^{\star}\end{array}$ \\
\hline
\end{tabular}

$1=$ heavy lifting $(>10 \mathrm{~kg}$ ) or patient transfers $5-49$ times/week

$2=$ heavy lifting $(>10 \mathrm{~kg})$ or patient transfers $\geqslant 50$ times/week

$\star \mathrm{p}<0.05$

Table II The distribution of the study population in the spontaneous abortion study by employer

\begin{tabular}{|c|c|c|c|c|c|c|}
\hline \multirow{2}{*}{$\begin{array}{l}\text { Employer } \\
\text { Hospital } \\
\text { Health care centre } \\
\text { Rehabilitating institute } \\
\text { Occupational health care } \\
\text { Private enterprise } \\
\text { Self employed } \\
\text { Other job }\end{array}$} & \multicolumn{2}{|c|}{ Cases $\left({ }^{\circ}{ }_{0}\right)$} & \multicolumn{2}{|c|}{ Controls $\left({ }_{0}{ }_{0}\right)$} & \multicolumn{2}{|c|}{ Total $\left({ }^{\circ}{ }_{0}\right)$} \\
\hline & $\begin{array}{r}52 \\
36 \\
4 \\
5 \\
32 \\
17 \\
24\end{array}$ & $\begin{array}{r}(30 \cdot 6) \\
(21 \cdot 2) \\
(2 \cdot 4) \\
(2 \cdot 9) \\
(18 \cdot 8) \\
(10 \cdot 0) \\
(14 \cdot 1)\end{array}$ & $\begin{array}{r}105 \\
72 \\
17 \\
13 \\
106 \\
43 \\
23\end{array}$ & $\begin{array}{r}(27.7) \\
(19.0) \\
(4.5) \\
(3.4) \\
(28.0) \\
(11.3) \\
(6.1)\end{array}$ & $\begin{array}{r}157 \\
108 \\
21 \\
18 \\
138 \\
60 \\
47\end{array}$ & $\begin{array}{r}(28 \cdot 6) \\
(19.7) \\
(3.8) \\
(3.3) \\
(25 \cdot 1) \\
(10.9) \\
(8.6)\end{array}$ \\
\hline Total & 170 & $(100 \cdot 0)$ & 379 & $(100 \cdot 0)$ & 549 & $(100 \cdot 0)$ \\
\hline
\end{tabular}

penetrate tissues. Ultrasound exposure was analysed separately, because the therapist holds the ultrasound emitter in her hand during the entire treatment session, and thus the exposure time is usually longer than with other equipment. The ultrasound waves used for therapeutic equipment usually have the frequency of $0.5-3 \mathrm{MHz}$. The electric current used in the treatment of pain (transcutaneous nerve stimulation, diadynamic currents, electrogalvanic stimulation, interference current, laser) and for the activation of the muscles (electric activation) were grouped together. Equipment producing superficial heat ("hydrocollator" packages, infrared and ultraviolet light) were also grouped together. The amount of exposure was classified according to the time which the therapist handled the equipment, standing close to it (at $\leqslant 1 \mathrm{~m}$ distance).

\section{STATISTICAL ANALYSIS}

The statistical analysis was done with linear logistic regression for individually matched data. ${ }^{8}$ The significance was evaluated by comparing the standardised parameter estimates with a normal distribution. The confidence intervals (CI) of parameters were calculated by means of the standard errors of the parameter estimates. The significance for homogeneity of the odds ratios according to the length of the gestation was determined by separating the strata where the case had the gestation time $\leqslant 10$ weeks from those having a gestation time $>10$ weeks by a dummy variable, and including the interaction of it with the exposure variable in the logistic model.

\section{Results}

SPONTANEOUS ABORTIONS

Initially 1047 physiotherapists were recruited to the spontaneous abortion study but only 1020 could be traced. The response rate was $92 \cdot 2^{\circ}{ }_{0}$ $\left(247 / 275=89.9^{\circ}\right.$ o for the cases and 693/ $745=93.0^{\circ}$ o for the controls). Only pregnancies which were reported in accordance with the hospital discharge or clinic records were accepted $\left(91.9 \%\right.$ for the cases and $99 \cdot 7^{\circ}$ of the controls). The final analysis consisted of 204 cases and 483 age matched controls.

The employment status of the study persons was as follows: $25\left(12^{\circ}{ }_{0}\right)$ of the cases and $61\left(13^{\circ}{ }_{0}\right)$ of the controls were not employed during the first three months of the pregnancy, six cases and 13 controls ( $3^{\circ}{ }_{0}$ from both) were studying, and 173 $\left(85^{\circ}\right)$ cases and $409\left(85^{\circ}{ }_{0}\right)$ controls were employed (table I). Hospital work was more common among the cases than the controls. Work in private enterprises and rehabilitating institutes was more common among the controls than the cases (table II).

Of the various forms of therapy, ultrasound was the most often reported exposure among the study persons. Handling of ultrasound equipment for at least 20 hours per week increased the risk of spontaneous abortion significantly $(O R=3.4$; table I). No distinction was made between ultrasound given in the air or in water, since no differences were noted in the preliminary analysis. The odds ratio was also increased for handling equipment producing electric currents 
for at least $5 \mathrm{~h}$ per week $(\mathrm{OR}=2 \cdot 0)$. Physical exertion (transferring patients or lifting heavy burdens more than 50 times per week) also increased the odds ratio of spontaneous abortions $(O R=3 \cdot 5)$ significantly. Patient tranfers were the most common form of physical exertion. The amount of massage or mobilisation therapy had no influence on the risk of spontaneous abortion.

In the analysis of occupational variables according to the length of the pregnancy (table III) physical exertion ( $\geqslant 50$ times per week) was

Table III Odds ratio of spontaneous abortions according to length of the pregnancy; univariate or bivariate logistic regression models

\begin{tabular}{|c|c|c|c|}
\hline \multirow[t]{2}{*}{ Variable } & \multicolumn{2}{|c|}{ Length of pregnancy } & \multirow{2}{*}{$\begin{array}{l}p \text { Value for the } \\
\text { homogeneity of the } \\
\text { odds ratios (OR } 1 \\
v \text { OR 2) }\end{array}$} \\
\hline & $\begin{array}{l}\leqslant 10 \text { weeks } \\
\text { OR } 1\end{array}$ & $\begin{array}{l}>10 \text { weeks } \\
\text { OR } 2\end{array}$ & \\
\hline $\begin{array}{c}\text { Deep heat therapy } \\
1-4 \mathrm{~h} / \text { week } \\
\geqslant 5 \mathrm{~h} / \text { week }\end{array}$ & $\begin{array}{l}1.3 \\
0.7\end{array}$ & $\begin{array}{l}1 \cdot 3 \\
2 \cdot 6 t\end{array}$ & $<0.05$ \\
\hline $\begin{array}{l}\text { Shortwaves } \\
1-4 \mathrm{~h} / \text { week } \\
\geqslant 5 \mathrm{~h} / \text { week } \\
\text { Microwaves }\end{array}$ & $\begin{array}{l}1 \cdot 2 \\
0.7 \\
1 \cdot 0\end{array}$ & $\begin{array}{l}1 \cdot 2 \\
2 \cdot 5 \dagger \\
2 \cdot 4\end{array}$ & $<0.05$ \\
\hline $\begin{array}{l}\text { Ultrasound } \\
\qquad \begin{array}{l}1-9 \mathrm{~h} / \text { week } \\
\geqslant 10 \mathrm{~h} / \text { week }\end{array}\end{array}$ & $\begin{array}{l}1 \cdot 0 \\
0.7\end{array}$ & $\begin{array}{l}1 \cdot 3 \\
3 \cdot 4 \dagger\end{array}$ & $<0.01$ \\
\hline $\begin{array}{c}\text { Electric therapies } \\
1-4 \mathrm{~h} / \text { week } \\
\geqslant 5 \mathrm{~h} / \text { week }\end{array}$ & $\begin{array}{l}1.0 \\
1.8\end{array}$ & $\begin{array}{l}1 \cdot 0 \\
2 \cdot 2\end{array}$ & \\
\hline $\begin{array}{l}\text { Diadynamic currents } \\
1-4 \mathrm{~h} / \text { week } \\
\geqslant 5 \mathrm{~h} / \text { week }\end{array}$ & $\begin{array}{l}1.3 \\
2.3\end{array}$ & $\begin{array}{l}0.9 \\
1.7\end{array}$ & \\
\hline $\begin{array}{l}\text { Transcutaneous nerve stimulation } \\
1-4 \mathrm{~h} / \text { week } \\
\geqslant 5 \mathrm{~h} / \text { week } \\
\text { Interference } \\
\text { Electric stimulation }\end{array}$ & $\begin{array}{l}1 \cdot 1 \\
1.9 \\
0.6 \\
0.7\end{array}$ & $\begin{array}{l}1 \cdot 0 \\
1.4 \\
1 \cdot 3 \\
1 \cdot 6\end{array}$ & \\
\hline $\begin{array}{l}\text { Superficial heat therapy } \\
1-4 \mathrm{~h} / \text { week } \\
\geqslant 5 \mathrm{~h} / \text { week }\end{array}$ & $\begin{array}{l}1.0 \\
0.7\end{array}$ & $\begin{array}{l}1 \cdot 2 \\
2 \cdot 0\end{array}$ & \\
\hline $\begin{array}{l}\text { Hydrocollator heating packages } \\
1-4 \mathrm{~h} / \text { week } \\
\geqslant 5 \mathrm{~h} / \text { week } \\
\text { Infrared }\end{array}$ & $\begin{array}{l}1.7 \\
0.5 \\
0.8\end{array}$ & $\begin{array}{l}1 \cdot 2 \\
1 \cdot 7^{\star}\end{array}$ & \\
\hline Heavy lifting $\frac{1^{a}}{2}$ & $\begin{array}{l}0 \cdot 8 \\
3 \cdot 8^{\star}\end{array}$ & $\begin{array}{l}1 \cdot 7^{\star} \\
6 \cdot 7^{\star}\end{array}$ & \\
\hline
\end{tabular}

a $1=$ heavy lifting ( $>10 \mathrm{~kg}$ ) or patient transfers $5-49$ times/week

$2=$ heavy lifting $(>10 \mathrm{~kg})$ or patient transfers $\geqslant 50$ times/week

$\star \mathrm{p}<0.05,+\mathrm{p}<0.01$

Table IV The odds ratio of the spontaneous abortion for potential confounding variables, univariate logistic regression models

\begin{tabular}{|c|c|c|c|}
\hline Factor & $\begin{array}{l}n \\
\text { (case/control) }\end{array}$ & $O R$ & $\begin{array}{l}95 \% \text { confidence } \\
\text { interval }\end{array}$ \\
\hline Alcohol ${ }_{2}^{a}$ & $\begin{array}{c}113 / 263 \\
8 / 22\end{array}$ & $\begin{array}{l}1 \cdot 0 \\
0 \cdot 8\end{array}$ & $\begin{array}{l}0 \cdot 7-1 \cdot 5 \\
0 \cdot 3-2 \cdot 1\end{array}$ \\
\hline Smoking & $10 / 43$ & $0 \cdot 5$ & $0 \cdot 2-1 \cdot 0^{\star}$ \\
\hline Previous deliveries $\begin{aligned} 1 \\
\geqslant 2\end{aligned}$ & $\begin{array}{l}74 / 177 \\
33 / 54\end{array}$ & $\begin{array}{l}1 \cdot 2 \\
1 \cdot 3\end{array}$ & $\begin{array}{l}0 \cdot 8-1 \cdot 7 \\
0 \cdot 7-2 \cdot 5\end{array}$ \\
\hline Previous induced abortions & $17 / 20$ & $1 \cdot 8$ & $1 \cdot 0-3 \cdot 5$ \\
\hline Previous spontaneous abortions & $7 / 10$ & $1 \cdot 7$ & $0 \cdot 6-4 \cdot 7$ \\
\hline $\begin{array}{l}\text { Previous induced or } \\
\text { spontaneous abortions }\end{array}$ & $23 / 30$ & $1 \cdot 8$ & $1 \cdot 0-3 \cdot 1^{\star}$ \\
\hline $\begin{array}{l}\text { Use of contraception at the } \\
\text { beginning of the pregnancy } \\
\text { (intrauterine device, oral } \\
\text { contraceptive, spermicide) } \\
\text { Intrauterine device } \\
\text { Oral contraception }\end{array}$ & $\begin{array}{c}19 / 24 \\
12 / 20 \\
3 / 4\end{array}$ & $\begin{array}{l}2.0 \\
1.5 \\
2.9\end{array}$ & $\begin{array}{l}1 \cdot 0-3 \cdot 7^{\star} \\
0 \cdot 7-3 \cdot 1 \\
0 \cdot 5-16 \cdot 6\end{array}$ \\
\hline $\begin{array}{l}\text { Febrile disease in the first trimester } \\
\text { of pregnancy }\end{array}$ & $25 / 71$ & $0 \cdot 8$ & $0.5-1 \cdot 3$ \\
\hline
\end{tabular}

a Alcohol 1 = less than 4.5 drinks ( $40 \mathrm{ml}$ strong alcohol or $120 \mathrm{ml}$ wine or $330 \mathrm{ml}$ beer)/week;

$2=4.5$ or more drinks/week

$2=4.5$ or
$\star \mathrm{p}<0.05$ the only significant risk factor $(\mathrm{OR}=3 \cdot 8)$ for early abortions (gestation $\leqslant 10$ weeks). The odds ratio of spontaneous abortions occurring after the 10th week was significantly increased for deep heat therapies given for $\geqslant 5 \mathrm{~h}$ per week $(\mathrm{OR}=2 \cdot 6)$, particularly for shortwaves $(O R=2 \cdot 5)$, and for ultrasound $\geqslant 10 \mathrm{~h}$ per week $(\mathrm{OR}=3 \cdot 4)$.

In the univariate analysis of the potential confounding factors, the failure of the contraception used (intrauterine device, oral contraceptive or spermicide) in the study pregnancy was associated significantly $(\mathrm{OR}=2 \cdot 0)$ with spontaneous abortion (table IV). A history of previous spontaneous or induced abortions also increased the odds ratio significantly $(O R=1 \cdot 8)$. The odds ratios of the confounding factors listed in table IV were not significantly different when the abortions in the early stage ( $\leqslant 10$ weeks) and later stage $(>10$ weeks) of pregnancy were compared.

The variables which showed an odds ratio over 1.5 in the analysis of the individual variables were included in the final multivariate model controlling for the effects of the variables on each other. Physical exertion and the history of previous abortions (induced or spontaneous) increased the odds ratios significantly $(O R=3.4$ and $1 \cdot 8$, respectively; table $\mathrm{V}$ ). The odds ratio for the use of ultrasound equipment for $>20 \mathrm{~h}$ per week was increased $(\mathrm{OR}=2 \cdot 3)$, but the increase was not statistically significant.

The odds ratios of spontaneous abortions for a few variables were calculated for the first and second half of the study. These variables were: handling of deep heat therapy equipment or ultrasound equipment, smoking, and alcohol consumption. The odds ratios were similar for the two halves of the study period.

\section{CONGENITAL MALFORMATIONS}

The congenital malformation study comprised 314 women ( 51 cases) of whom 309 study persons could be traced. The response rate was $88.7^{\circ}$ o $(47 / 51=92.2 \%$ for the cases, and 227) $258=88.0 \%$ for the controls). Among the cases $97.8 \%$, and among the controls $99.5{ }^{\circ}$, confirmed the pregnancy recorded in the register. In the final analysis there were 46 cases and 187 age matched controls.

In the analysis of individual factors (table VI) deep heat therapy and the handling of shortwave equipment $1-4 \mathrm{~h}$ per week increased the odds ratio for congenital malformation significantly $(\mathrm{OR}=2 \cdot 4$ and $2 \cdot 7$, respectively), but the odds ratio in the highest exposure category $(\geqslant 5 \mathrm{~h}$ per week) was $\leqslant 1 \cdot 0$. The other significant finding was the increased odds ratio $(\mathrm{OR}=4 \cdot 7)$ relating to transcutaneous nerve stimulation $\geqslant 5 \mathrm{~h}$ per week, but this was based on four cases only.

None of the potential confounding factors (as in the spontaneous abortion study, see table IV) showed significantly increased odds ratios. The odds ratio was increased if the woman had had two or more previous deliveries $\left(\mathrm{OR}=2 \cdot 5,95^{\circ}{ }_{\circ} \mathrm{CI}\right.$ $0 \cdot 6-10 \cdot 7)$ or a febrile disease during the first trimester $(\mathrm{OR}=1 \cdot 8,95 \%$ CI $0 \cdot 9-3 \cdot 6)$.

In the multivariate analysis controlling for the number of variables, the use of deep heat therapies and shortwaves was associated significantly with 
congenital malformations $(\mathrm{OR}=2 \cdot 2$ and $2 \cdot 3$, respectively; table VII). Use of electric therapy equipment and transcutaneous nerve stimulation in the high exposure category caused an increased odds ratio for congenital malformation, but the results were not statistically significant. In the multivariate model the odds ratio of febrile disease during the first three months of pregnancy was significantly increased $(\mathrm{OR}=2 \cdot 2)$.

Table $V$ The odds ratio of spontaneous abortion for the occupational variables and other factors adjusted with each other, multivariate logistic regression model

\begin{tabular}{lll}
\hline Variable & $O R$ & $\begin{array}{l}95^{\circ} \text { confidence } \\
\text { interval }\end{array}$ \\
\hline Ultrasound $\geqslant 20 \mathrm{~h} /$ week & $2 \cdot 3$ & $0.7-7.2$ \\
$\begin{array}{l}\text { Electric therapies } \\
\quad 55 \mathrm{~h} / \text { week }\end{array}$ & 1.6 & $0.7-3.5$ \\
Heavy lifting $2^{\mathrm{a}}$ & 3.4 & $1.3-8.7^{\star}$ \\
Previous induced or spontaneous abortions & 1.8 & $1.0-3.2^{\star}$ \\
Contraception at the beginning of pregnancy & 1.8 & $0.9-3.6$ \\
\hline
\end{tabular}

$2=$ Patient transfers or heavy lifting $(>10 \mathrm{~kg})>50$ times per week

${ }^{\star} \mathrm{p}<0.05$

Table VI The odds ratio of congenital malformations for individual occupational variables, logistic regression models

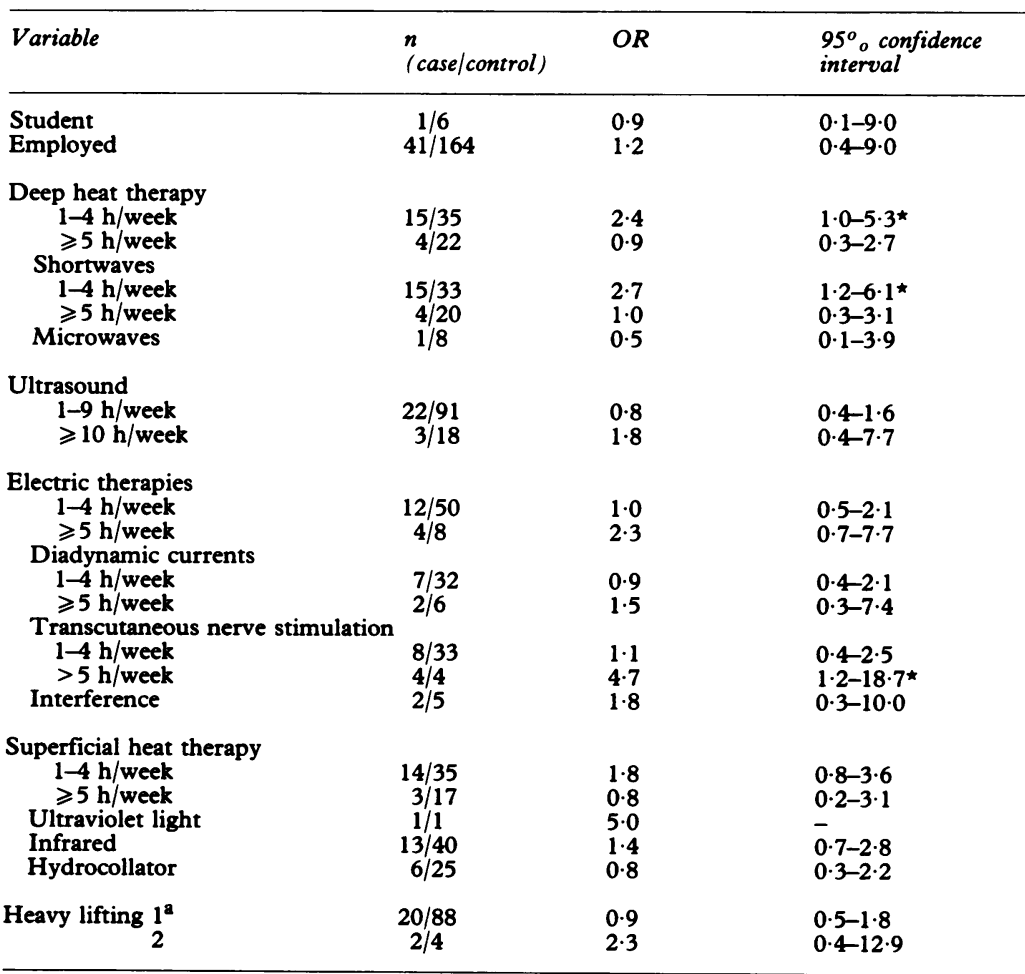

a 1 heavy lifting ( $>10 \mathrm{~kg}$ ) or patient transfers $5-49$ times/week

$2=$ heavy lifting $(>10 \mathrm{~kg})$ or patient transfers $\geqslant 50$ times/week

$\star p<0.05$

Table VII The odds ratio of congenital malformation for the occupational variables and other factors adjusted with each other, multivariate logistic regression models

\begin{tabular}{lll}
\hline Variables & Model 1 $\left(95^{\circ}{ }_{o} \mathrm{CI}\right)$ & Model 2 $\left(95^{\circ}{ }_{o} \mathrm{CI}\right)$ \\
\hline $\begin{array}{l}\text { Deep heat therapies }(>1 \mathrm{~h} / \text { week }) \\
\text { Shortwaves }(>1 \mathrm{~h} / \text { week })\end{array}$ & $2 \cdot 3(1 \cdot 1-5 \cdot 2)^{\star}$ & $2 \cdot 2(1 \cdot 0-4 \cdot 9)^{\star}$ \\
$\begin{array}{l}\text { Electric therapies }(\geqslant 5 \mathrm{~h} / \text { week }) \\
\text { TNS }(\geqslant 5 \mathrm{~h} / \mathrm{week})\end{array}$ & $3.3(0 \cdot 8-14 \cdot 1)$ & $2 \cdot 4(0 \cdot 6-8 \cdot 7)$ \\
Parity $(\geqslant 2)$ & $2 \cdot 9(0 \cdot 7-12 \cdot 9)$ & $3.0(0 \cdot 7-12 \cdot 9)$ \\
Febrile diseases & $2 \cdot 2(1 \cdot 0-4 \cdot 8)$ & $2 \cdot 2(1 \cdot 0-5 \cdot 0)^{\star}$ \\
\hline
\end{tabular}

${ }^{\star} \mathrm{p}<0.05$

${ }_{\text {TNS }}^{\star} \mathrm{p}<\mathrm{Transcutaneous} \mathrm{nerve} \mathrm{stimulation}$

\section{Discussion}

In this study we tried to avoid as many as possible of the potential biases of epidemiological studies. For example, the information on pregnancy outcome was reliable when it was based on medical registers and confirmed by respondents. Physiotherapists' reports of the pregnancy outcome were in good agreement with the register data. Nurses had also done so in an earlier study ${ }^{9}$. The agreement in this study was higher than in a study on dry cleaning workers and workers exposed to organic solvents, ${ }^{6}$ which is probably due to a better awareness of biomedical events among health care personnel than among industrial workers.

A bias due to selective participation is not likely in this study since the response rates were high and fairly similar for both the cases and the controls. Selective reporting or recall of the exposure, if present, may cause bias. However, four aspects of the results tend to exclude this bias: dose-response relationships, effects of gestational length, differences in results between spontaneous abortions and malformations (because bias should affect them in the same way), and uniformity of effects between the two periods analysed.

Exposure to shortwaves and ultrasound was correlated with medically diagnosed spontaneous abortions occurring after the tenth week of pregnancy but not with those occurring earlier. This points to a real association rather than to a reporting bias. Also $\mathrm{McDonald}$ et al $^{10}$ have observed increased risk for late abortions (length of gestation $\geqslant 16$ weeks) but not for early abortions in some occupational groups, eg, operating room nurses.

Selective recall in the malformation part of the study cannot be excluded, since the risk was increased among physiotherapists using shortwave equipment $1-4 \mathrm{~h}$ per week but not among those using shortwaves $>4 \mathrm{~h}$ per week. Such a finding could be due to the cases reporting slight exposures more than the controls.

Since the study period covered 11 years retrospectively, the potential effect of differential recall was estimated by calculating the odds ratios of spontaneous abortions separately for the first and second half of the study period. The odds ratios for a few occupational and life style factors were similar in the two halves of the study period. This finding further reassures us that no major bias in the spontaneous abortion study was caused by differential recall or reporting problems. However, some of the significant associations may be due to chance, since multiple comparisons were made.

According to the profile analysis, $40-50^{\circ}{ }_{0}$ of the physiotherapists' working time in private enterprises consisted of dynamic work, eg, massage and mobilisation therapy. In hospitals the work is often done in a bent position, and there are short peaks of physical strain, eg, when patients are helped out of bed. The work in health care centres included little physical strain. ${ }^{11}$ However, in this study the individually reported physical exertion was a better indicator of the risk for spontaneous abortions than employment in work places where dynamic work was expected to be most common. The association of heavy lifting 
and preterm births ${ }^{12} 13$ and spontaneous abortions $^{14-16}$ has been reported earlier. However, in one retrospective ${ }^{17}$ and one prospective study ${ }^{18}$ such associations have not been found.

In earlier studies no increase in the risk of spontaneous abortion among physiotherapists was found. ${ }^{313}$ However, in a case-control study conducted as a part of Källen's study, ${ }^{3}$ an increased risk of adverse pregnancy outcome (congenital malformation and perinatal death) was found among physiotherapists who used shortwaves often during their pregnancy. Other case-control studies have not revealed any association between congenital malformation and exposure to shortwaves (or microwaves) during pregnancy. ${ }^{1319}$ In Denmark four of 25 pregnancies of physiotherapists during 1979-84 in one hospital ended in the birth of a malformed child and two in a spontaneous abortion. The mothers of the malformed children had been working near shortwave equipment during their pregnancy. Hygienic measurements conducted in 1984 in the same hospital showed electric fields of $20-220 \mathrm{~V} / \mathrm{m}$ and magnetic fields up to $0.55 \mathrm{~A} / \mathrm{m}$ at a distance of $0.5 \mathrm{~m}$ from the equipment. ${ }^{20}$ The highest measurements exceeded the Finnish hygienic standards (see below). Reports on patients receiving shortwave treatment in the pelvic region during pregnancy have shown conflicting results; some women have had offspring with congenital defects, other have had normal children and no problems in reproduction. ${ }^{21}$

In general, exposure to shortwaves in the Finnish physiotherapy departments seems to be under control, since none of the 1440 hygienic measurements conducted by the Institute of Occupational Health in 1977-84 exceeded the hygienic standard in Finland $(60 \mathrm{~V} / \mathrm{m}$ electric fields and $0.2 \mathrm{~A} / \mathrm{m}$ magnetic fields, when the exposure time is $\geqslant 2 \mathrm{~h}$ per day). On the other hand, the hygienic standards are not based on reproductive effects and cannot therefore be considered as completely safe during pregnancy.

Little is known about the mechanisms by which shortwaves might harm the pregnancy or cause damage to the offspring. In mammals shortwaves are teratogenic and embryolethal at intensities which produce significant hyperthermia in the dams. $^{22}$ It is not known whether occupational exposure of physiotherapists could produce hyperthermia in the embryo or the fetus of pregnant women. Although a non-thermal effect has not been clearly shown, this possibility is still being investigated. ${ }^{2}$

The finding that high exposure to ultrasound increased the risk for "late" (gestation time $>10$ weeks) spontaneous abortion raises the question of the potential hazards of diagnostic ultrasound commonly used during pregnancy. Two randomised trials on routine ultrasound screening (in the 16th week of gestation or later) did not reveal any increased risk for spontaneous abortion $(R R=1.2$ and 0.66$) .{ }^{2324}$ No studies are available on the effects of ultrasound on early pregnancy.

As ultrasound is not propagated markedly in air, the therapist could be exposed only through direct or indirect contact (via solid or liquid material) with the ultrasound emitter. Direct contact during physiotherapy between ultrasound and the abdominal organs of the therapist appears very unlikely. The measured intensity of scattered ultrasound from the handles of the emitter has been very low, below $0.1 \mathrm{~mW} / \mathrm{cm}^{2} .{ }^{25}$ The power intensity of $100 \mathrm{~mW} / \mathrm{cm}^{2}$ is considered as a safety limit for therapeutic equipment. ${ }^{26}$ Electric fields around electric equipment might also be a potential hazard, but little is known of their effects.

Ultrasound penetrates mammalian tissues and propogates molecular oscillation. Ultrasound over $100 \mathrm{~mW} / \mathrm{cm}^{2}$ for several seconds raises the temperature of experimental animals and may cause changes in tissues and mechanical rupturing of biological membranes. In pregnant mice ultrasound at an intensity of $2.0 \mathrm{~W} / \mathrm{cm}^{2}$ has caused abnormality in fetuses, and at an intensity of $45 \mathrm{~W} / \mathrm{cm}^{2}$ a reduction in litter size, lower pup weight, and anomalies. The intensity of exposure in animal experiments was, however, much higher $\left(45 \mathrm{~W} / \mathrm{cm}^{2}\right)$ than that used in medical equipment. $^{27}$

The results of this study suggest that heavy physical exertion is a risk factor for spontaneous abortion. The effect of shortwaves and ultrasound on the "late" spontaneous abortions was significant and increased in a dose related manner. On the other hand, in the multivariate analyses neither the effects of ultrasound nor shortwaves reached statistical significance. Therefore, the finding has to be interpreted cautiously. The finding of an association between the exposure to shortwaves and congenital malformations does not justify conclusions of a causal relationship.

We thank Marja-Liisa Lindbohm, MA, for valuable comments during the study and Ms Tarja Nikula for skilful technical assistance. This study was supported by grant No. 173/85 from the Finnish Work Environment Fund.

1 National Council on Radiation Protection. Biological effects and exposure criteria for radiofrequency electromagnetic and exposure criteria for radiofrequency electromagnetic Radiation Protection and Measurements Report 86, Radiation Protection and

2 Brent R. The effect of embryonic and fetal exposure to $x$-ray, microwaves and ultrasound. Clin Perinatol 1986; 13: $615-48$. 3 Källen B, Malmqvist G, Moritz U. Delivery outcome among
physiotherapists in Sweden: is non-ionizing radiation a fetal hazard? Arch Environ Health 1982; 32: 81-5.

4 Kolmodin-Hedman B, Hanssons Mild K, Hagberg E, Jönsson E, Andersson M-C, Eriksson A. Health problems among operators of plastic welding machines and exposure to radiofrequency electromagnetic fields. Int Arch Occup Environ Health 1986; 60: 243-7.

5 Goulet L, Thériault G. Association between spontaneous Goulet $L$, Theriault $G$. Association between spontaneous
abortion and ergonomic factors. A literature review of the epidemiologic evidence. Scand $\mathcal{f}$ Work Environ Health 1987; 13: 399-403.

6 Lindbohm M-L, Hemminki K. Nation-wide data base on medically diagnosed spontaneous abortions in Finland. Int 7 Epidemiol 1988; 17: 568-79.

7 Saxen L. Twenty years of study of the etiology of congenital malformations in Finland. In: Kalter $\mathrm{H}$, ed. Issues and reviews in teratology. New York: Plenum Publishing Corporation 1983: 73-110.

8 Breslow NE, Day NE. Statistical methods in cancer research: the analysis of case-control studies. Lyon: International Agency for Research on Cancer, 1980.

9 Selevan SG, Lindbohm M-L, Hornung RW, Hemminki K. A study of occupational exposure to antineoplastic drugs A study of occupational exposure to antineoplastic drugs
and fetal loss in nurses. $N$ Engl $f$ Med 1985; 313: 1173-8. 10 McDonald AD, McDonald JC, Armstrong B, et al. Fetal McDonald AD, McDonald JC, Armstrong B, et al. Fetal
Death and work in pregnancy. Br $\mathcal{J}$ Ind Med 1988; 45: Death and

11 Savola E, Suvitie T. The description of physiotherapist's work with the AET-method (in Finnish). Report of a study. Turku, Finland: School of nursing, 1985. 
12 Mamelle N, Laumon B, Lazar P. Prematurity and occupational activity during pregnancy. Am $\mathcal{Y}$ Epidemiol 1984; 119: 309-22.

13 McDonald A, McDonald JC, Armstrong B, et al. Occupation and pregnancy outcome. Br f Ind Med 1987; 44: $521-6$.

14 Taskinen $H$, Lindbohm M-L, Hemminki K. Spontaneous abortions among women working in the pharmaceutical industry. Br $F$ Ind Med 1986; 43: 199-205.

15 Kyyrönen $P$, Taskinen $H$, Lindbohm M-L, Hemminki $K$, Heinonen OP. Spontaneous abortions and congenital malformations among women exposed to trichloroethylene in dry cleaning. $\mathcal{J}$ Epidemiol Community Health 1989; 43 in dry clear 51 .

16 Taskinen H, Anttila A, Lindbohm M-L, Sallmén $M$, Hemminki $K$. Spontaneous abortions and congenital malformations among the wives of men occupationally exposed to organic solvents. Scand $\mathcal{F}$ Work Environ Health 1989; 15: $345-52$

17 Axelsson G, Lutz C, Rylander R. Exposure to solvents and outcome of pregnancy in university laboratory employees. Br F Ind Med 1984; 41: 305-12.

18 Ahlborg G, Hogstedt C, Bodin L, Bárány S. Pregnancy outcome among working women: a prospective study. Scand $\mathcal{Y}$ Work Environ Health 1989; 15: 227-33.

19 Kurppa K, Holmberg PC, Hernberg S, Rantala K, Riala R Nurminen $T$. Screening for occupational exposures and congenital malformations. Preliminary results from a nationwide case-referent study. Scand $\mathcal{f}$ Work Environ Health 1983; 9: 89-93.

20 Larsen AI, Jensen AO, Skotte J, Istre O. Does non-ionizing radiation influence foetal development? Ugeskr Laeger 1987; 149: 518-20 (in Danish with English summary).

21 Roberts NJ, Michaelson SM. Epidemiological studies of human exposures to radiofrequency radiation. A critical human exposures to radiofrequency radiation. A

22 review. Int Arch Occup Health 1985; 56: 169-78. response relationship between body temperature and response relationship between body temperature and
birth defects in radiofrequency-irradiated rats. birth defects in radiofreque
Bioelectromagnetics 1986; 7: 141-9.

23 Bennet MJ, Little G, Dewhurst J, Chamberlain G. Predictive value of ultrasound measurement in early pregnancy: a randomised controlled trial. $\mathrm{Br} \mathcal{F}$ Obstet Gynaecol 1982; 89: 338-41.

24 Bakketeig LS, Eik-Nes SH, Jacobsen G, et al. Randomised controlled trial of ultrasonographic screening in pregnancy. Lancet 1984; ii: $207-11$.

25 World Health Organisation. Nonionizing radiation protection. Copenhagen: WHO Regional Publications (European series No. 10), 1982.

26 Wiernicki C, Karoly W. Ultrasound: biological effects and industrial hygiene concerns. Am Ind Hyg Assoc $₹$ 1985; 46: 488-96. 